\title{
PELAKSANAAN CUCI TANGAN PAKAI SABUN DALAM MENGGALAKKAN GERAKAN MASYARAKAT SEHAT (GERMAS) DI KELURAHAN MAHARANI KECAMATAN RUMBAI
}

\author{
Kiki Megasari, Eka Maya Saputri \\ STIKes Hang Tuah Pekanbaru
}

\begin{abstract}
Hand washing is the most important basic technique in the prevention and control of infection (Potter \& Perry, 2005). Hand washing is the process of removing dirt and dust mechanically from both hands using soap and water. The purpose of hand washing is to mechanically remove dirt and grime from the surface of the skin and reduce the number of microorganisms. Washing hands can also eliminate a large number of viruses that cause various diseases, especially diseases that attack the gastrointestinal tract, such as diarrhea and respiratory tract such as influenza. Almost everyone understands the importance of washing hands with soap, but there are still many who do not get in the habit of getting it right at important times. These problems arise due to a lack of knowledge and awareness of the importance of health, especially hand washing habits. Washing hands is an inexpensive and effective way to prevent infectious diseases. However, until now this habit is often underestimated. By providing counseling on hand washing, it is hoped that these infectious diseases can reduce the risk of disease transmission through hands by washing hands. Food and drinks cooked with dirty hands can transmit disease, try to wash your hands with running water and soap when you are going to prepare and eat food and after defecating. The purpose of this community service is to increase awareness of the community on the importance of washing hands with soap with running water so that health is maintained. The method of activities carried out is to provide health education and practice to all activity participants how to wash their hands with soap properly and correctly. The results of the implementation of the activity: the activity participants know, understand and understand the importance of washing hands with soap for personal health. It is recommended that health workers and schools always remind the public and students about the importance of washing their hands with soap so that the behavior of people who rarely wash their hands after carrying out various activities will not be repeated in order to improve the community's health status.
\end{abstract}

Keywords: Wash your hands with soap

\begin{abstract}
ABSTRAK
Mencuci tangan merupakan teknik dasar yang paling pentingdalam pencegahan dan pengontrolan infeksi (Potter \& Perry, 2005).Mencuci tangan merupakan proses pembuangan kotoran dan debu secara mekanis dari kedua belah tangan dengan memakai sabun dan air. Tujuan cuci tangan adalah untuk menghilangkan kotoran dan debu secara mekanis dari permukaan kulit dan mengurangi jumlah mikroorganisme. Mencuci tangan juga dapat menghilangkan sejumlah besar virus yang menjadi penyebab berbagai penyakit, terutama penyakit yang menyerang saluran cerna, seperti diare dan saluran nafas seperti influenza. Hampir semua orang mengerti pentingnya mencuci tangan pakai sabun, namun masih banyak yang tidak membiasakan diri untuk melakukan dengan benar pada saat yang penting. Masalah-masalah tersebut timbul karena kurangnya pengetahuan serta kesadaran
\end{abstract}


akan pentingnya kesehatan terutama kebiasaan mencuci tangan. Cuci tangan merupakan cara murah dan efektif dalam pencegahan penyakit menular. Namun hingga saat ini kebiasaaan tersebut seringkali dianggap remeh. Dengan memberikan penyuluhan tentang cuci tangan diharapkan penyakit menular tersebut bisa mengurangi resiko terjadinya penularan penyakit melalui tangan dengan mencuci bersih tangan. Makanan dan minuman yang dimasak dengan tangan kotor itu dapat menularkan penyakit, cobalah mencuci tangan anda dengan air menalir dan sabun pada saat anda akan mempersiapkan dan memakan makanan serta sesudah berak. Tujuan Pengabdian kepada masyarakat ini adalah untuk meningkatkan kepedulian kepada masyarakat arti pentingnya mencuci tangan pakai sabun dengan air yang mengalir agar tetap kesehatan tetap terjaga. Metode kegiatan ynng dilaksanakan adalah melakukan penyuluhan kesehatan dan mempraktikkan kepada seluruh peserta kegiatan bagaimana cara mencuci tangan pakai sabun yang baik dan benar. Hasil pelaksanaan kegiatan: para peserta kegiatan mengetahui, mengerti dan memahami akan pentingnya mencuci tangan pakai sabun bagi kesehatan diri. Disarankan kepada tenaga kesehatan dan pihak sekolah untuk dapat selalu mengingatkan masyarakat dan peserta didik tentang pentingnya mencuci tangan pakai sabun agar perilaku masyarakat yang jarang mencuci tangan setelah melakukan berbagai kegiatan tidak terulang lagi demi meningkatkan derajat kesehatan masyarakat.

\section{Kata Kunci : Mencuci Tangan Pakai Sabun}

\section{PENDAHULUAN}

\begin{abstract}
Mencuci tangan merupakan teknik dasar yang paling pentingdalam pencegahan dan pengontrolan infeksi (Potter \& Perry, 2005).Mencuci tangan merupakan proses pembuangan kotoran dan debu secara mekanis dari kedua belah tangan dengan memakai sabun dan air. Tujuan cuci tangan adalah untuk menghilangkan kotoran dan debu secara mekanis dari permukaan kulit dan mengurangi jumlah mikroorganisme.

Mencuci tangan juga dapat
menghilangkan sejumlah besar virus
yang menjadi penyebab berbagai
penyakit, terutama penyakit yang
menyerang saluran cerna, seperti diare
\end{abstract}

dan saluran nafas seperti influenza. Hampir semua orang mengerti pentingnya mencuci tangan pakai sabun, namun masih banyak yang tidak membiasakan diri untuk melakukan dengan benar pada saat yang penting.

Masalah-masalah tersebut timbul karena kurangnya pengetahuan serta kesadaran akan pentingnya kesehatan terutama kebiasaan mencuci tangan. Cuci tangan merupakan cara murah dan efektif dalam pencegahan penyakit menular. Namun hingga saat ini kebiasaaan tersebut seringkali dianggap remeh.

Dengan memberikan penyuluhan tentang cuci tangan diharapkan penyakit 
menular tersebut bisa mengurangi resiko terjadinya penularan penyakit melalui tangan dengan mencuci bersih tangan. Makanan dan minuman yang dimasak dengan tangan kotor itu dapat menularkan penyakit, cobalah mencuci tangan anda dengan air menalir dan sabun pada saat anda akan mempersiapkan dan memakan makanan serta sesudah berak.

\section{PERUMUSAN MASALAH}

Masih banyaknya masyarakat di Kelurahan Maharani Kecamatan Rumbai yang tidak mengetahu tentang pentingnya mencuci tangan pakai sabun sehingga rentan diantara mereka menginap penyakit yang disebabkan oleh kuman atau bakteri yang masuk ke dalam mulut akibat dari tidak mencuci tangan pakai sabun saat setelah melakukan berbagai kegiatan dan yang terpenting adalah saat sebelum makan.

\section{TUJUAN KEGIATAN}

Kegiatan Pengabdian kepada masyarakat ini dilaksanakan untuk memberi pengetahuan kepada masyarakat Kelurahan Maharani Kecamatan Rumbai tentang pentingnya cuci tangan pakai sabun dan bahayanya jika tidak mencuci tangan pakai sabun sehingga dapat meningkatkan kesadaran dan kesehatan masyarakat akan pentingnya mencuci tangan pakai sabun dengan harapan nantinya mereka terbiasa untuk selalu mencuci tangan pakai sabun baik setelah melakukan kegiatan ataupun sebelum makan.

\section{METODE KEGIATAN}

\section{Kerangka Pemecahan Masalah}

Masih banyak ditemukannya masyarakat di Kelurahan Maharani Kecamatan Rumbai yang belum mengetahui tentang pentingnya mencuci tangan pakai sabun. Kebanayak mereka mencuci tangan hanya sekedar basah saja. Padahal jika mereka menyadari bahwa masih banyak kuman dan bakteri yang menempel pada tangan apabila tangan tersebut tidak dicuci dengan sabun dan air yang mengalir. Untuk merubah perilaku mereka agar sadar betapa pentingnya mencuci tangan pakai sabun dan juga merupakan salah satu langkah upaya meningkatkan kesehatan masyarakat, oleh karena itu dalam kegiatan pengabdian kepada masyarakat ini dilakukanlah penyuluhan kesehatan kepada masyarakat Kelurahan Maharani Kecamatan Rumbai dan juga dilakukan praktik mencuci tangan bersama masyarakat yang datang dalam pelaksanaan keguatan pengabdian kepada masyarakat. 


\section{Rancangan Evaluasi}

Evaluasi dilakukan dengan cara mengulas kembali materi melalui diskusi dan tanya jawab dengan indikator pencapaian masyarakat yang telah diberi penyuluhan kesehatan mengetahui dan memahami dengan benar tentang pentingnya mencuci tangan pakai sabun serta dapat mempraktikkan dalam kehidupan sehari-hari agar terhindar dari berbagai macam penyakit yang disebabkan oleh kuman dan bakteri yang bersumber dari tidak bersihnya tangan saat makan.

\section{Metode Kegiatan}

Metode kegiatan yang dilaksanakan adalah melakukan penyuluhan kesehatan tentang pentingnya mencuci tangan pakai sabun, kemudian melakukan demonstrasi mencuci tangan pakai sabun dengan air mengalir dan sabun cair. Masyarakat yang mengikuti kegiatan pengabdian kepada masyarakat ini juga diberikan kesempatan untuk mencuci tangan pakai sabun menggunakan air yang mengalir agar dapat mempraktikkan secara langsung bagaimana teknik mencuci tangan pakai sabun yang baik dan benar. Selanjutnya dilakukan evaluasi untuk mengetahui sejauh mana pengetahuan dan pemahaman yang diserap oleh para peserta penyuluhan tersebut tersebut. Evaluasi dilakukan melalui diskusi tanya jawab tentang materi pentingnya mencuci tangan pakai sabun yang sudah diberikan.

\section{HASIL}

Kegiatan pengabdian pada masyarakat ini memberikan hasil bahwa peserta kegiatan penyukuhan ini telah mengetahu, mengerti menanggapi dan memahami tentang pentingnya mencuci tangan pakai sabun. Mereka juga telah mengetahui, mengerti dan memahami apa saja akibat dari tidak mencuci tangan pakai sabun sehingga berdampak pada kesehatan mereka. Dengan demikian dapat merubah perilaku mereka menjadi lebih baik untuk dapat selalu mencuci tangan pakai sabun dengan menggunakan air yang mengalir demi menghindari diri dari berbagai penyakit yang bersumber dari tangan yang kotor.

\section{PEMBAHASAN}

Meningkatkan pengetahuan dan pemahaman seseorang tentang sesuatu hal sehingga diharapkan seseorang tersebut bertindak kearah yang lebih baik dalam ia berperilaku membutuhkan suatu stimulus. Intensitas stimulus yang diberikan tidak dapat hanya sesekali saja jika ingin hasil perilaku yang maksimal. 
Semakin sering stimulus diberikan dengan berbagai variasi cara diterimanya, maka semakin lengkap pemahaman yang diterimanya sehingga dapat bertindak semakin terarah atau tepat (Notoatmodjo, 2010).

Demikian pula halnya dengan upaya yang dilakukan untuk merubah perilaku masyarakat agar dapat melkukan cuci tangan pakai sabun setiap hari setelah melakukan kegiatan apapun dan sebelum makan Perlu upaya yang kreatif untuk dapat menstimulus perilaku masyarakat tersebut sehingga pada akhirnya diharapkan tercapainya program pemerintah. Bukan hanya penyuluhan saja yang disajikan kepada mereka dalam upaya merubah perilaku mereka, namun melakukan demonstrasi atas materi yang disampaikan dan memohon bantuan pihak terkait seperti tenaga kesehatn di Puskesmas, para guru di sekolah, para kader di lingkungan masyarakat dan para orang tua diharapkan dapat meberikan pendidikan kesehatan kepada masyarakatnya atau anak anakmya terkait tentang pentingnya mencuci tangan pakai sabun. Disamping itu juga, memberikan cendera mata yang bermanfaat bagi mereka merupakan salah satu upaya memberikan stimulus kepada mereka.

\section{KESIMPULAN}

Pengetahuan peserta penyuluhan kesehatan menjadi lebih meningkat tentang pentingnya mencuci tangan pakai sabun. Dan mereka juga berjanji dan memahami serta meyadari akan selalu menjaga kebersihan diri mereka salah satunya menjaga kebersihan tangan agar terhindar dari berbagai penyakit yang bersumber dari tangan yang kotor

\section{SARAN}

Perlu adanya peningkatan kegiatan Komunikasi, Informasi dan Edukasi (KIE) Secara terus menerus dengan melibatkan masyarakat dalam setiap pertemuan Posyandu dalam rangka meningkatkan perilaku cuci tangan pakai sabun. Perlua adanya sosialisasi perilaku cuci tangan pakai sabun dengan menggunakan media-media informasi yang diletakkan di tempat-tempat strategis sehingga informasinya mudah diakses oleh masyarakat.

\section{DAFTAR PUSTAKA}

Rifky, Muhammad.Selasa, 16 April 2013.Bahaya Tidak Mencuci Tangan

Sebelum

Makanhttp://dokumenrifky.blogspo

t.co.id/2013/04/bahaya-tidak-

mencucitangan-sebelum.html.

Jumat, 8 Januari 2016/ 16:24 
Unilever PLC/Unilever NV

2015.Asyiknya Mengajak Si Kecil

Cuci

Tangan.http://www.lifebuoy.co.id/h

ealthmap/health-news/asyiknya-

mengajak-si-kecil-cuci-tangan.

Jumat, 8 Januari 2016/ 15:18

Cara Membuat Kebiasaan Mencuci

Tangan Jadi Hal Seru

Dirumah.http://www.wafertango.co

$\mathrm{m} /$ index.php?page=readshare-

detail\&id=3072. Jumat, 8 Januari

2016/ 15:26

Basri, Hasan .Sabtu, 15 Juni 2013.7

LANGKAH CARA MENCUCI
TANGAN YANG BENAR

MENURUT

WHO.http://aciilsem.blogspot.co.id/

2013/06/7-langkah-cara-mencuci-

tangan-yang.html. Rabu, 6 Januari

2015/ 18:29

Yana, Yuli.7 Maret 2015. Manfaat

Mencuci Tangan Dengan Air

Bersih dan Sabun.

http://manfaat.co.id/manfaat-

mencuci-tangan-dengan-air-bersih-

dan-sabun. Rabu, 6 Januari 2015/

$18: 21$ 